\title{
Rock Gods of the Anthropocene: The biographical films of Elvis Presley and Jim Morrison
}

\author{
Bridget Sutherland
}

Eastern Institute of Technology, Napier, New Zealand/Aotearoa bridgetis@eit.ac.nz

Paul Judge

Independent, Hamilton, New Zealand/Aotearoa

pauljudge@xtra.co.nz

\begin{abstract}
Reflecting on the biographical films of Elvis Presley and Jim Morrison in relation to recent eco-critical theory and notions of the Anthropocene, we consider the representation of the rock star in the biopic genre and the ways in which music and other filmic elements may communicate ecological material. We consider the links between ecology and rock music, focusing on both the representation of nature in the films and the symbolism of the body as primal, as animal, and as "creaturely poetic" (Pick, 2011: 5). In a comparison between the biopics Elvis from 1979, by John Carpenter, and The Doors, from 1991, by Oliver Stone, we examine common motifs and the ways in which these differing cultural texts foreground or repress ecological readings of the music and of the cinematic narrative.
\end{abstract}

KEY WORDS: Eco-criticism, eco-musicology, eco-cinema, Elvis, The Doors.

IASPM@journal vol.7 no.1 (2017)

Journal of the International Association for the Study of Popular Music

ISSN 2079-3871 I DOI 10.5429/2079-3871(2017)v7i1.6en I www.iaspmjournal.net 


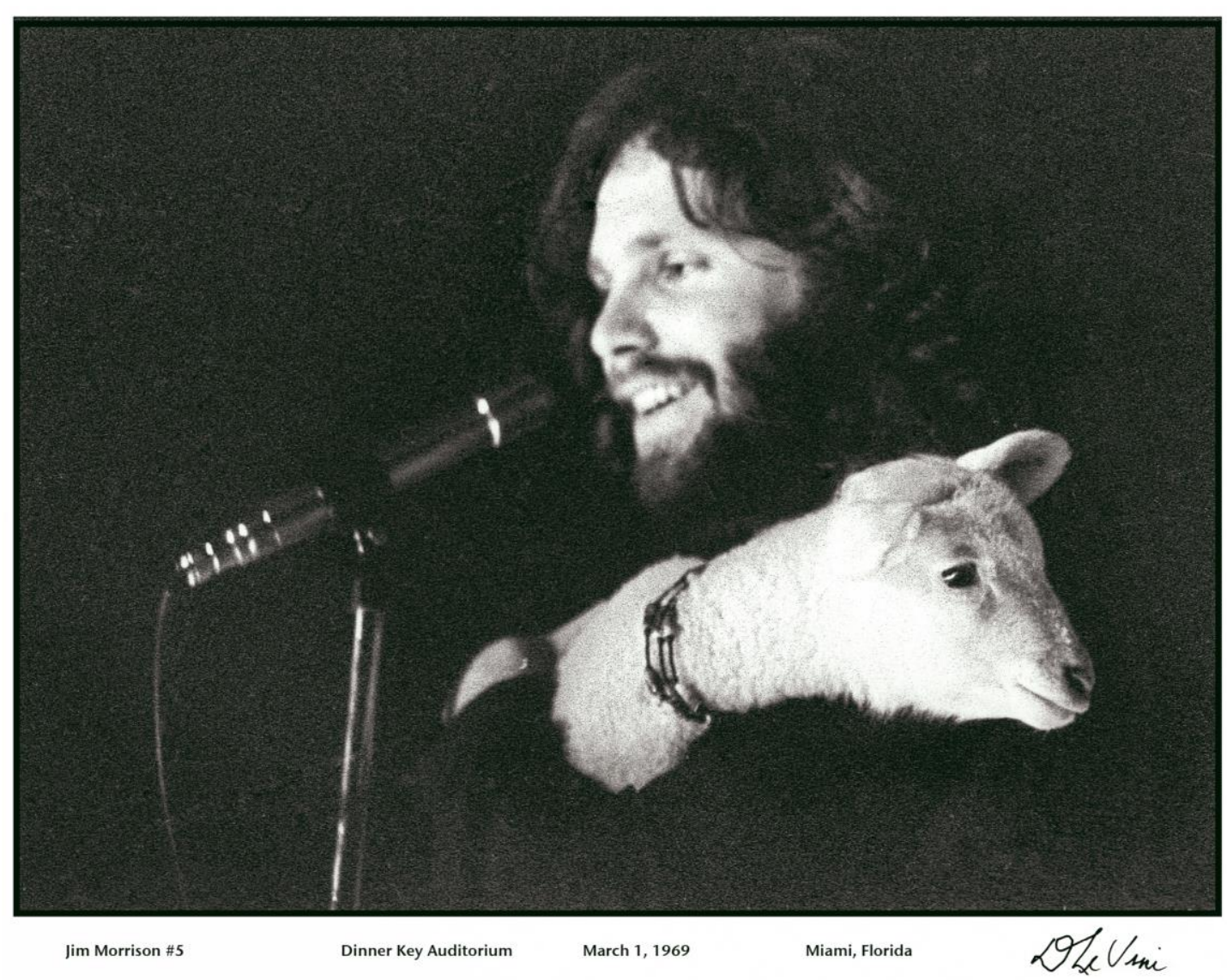

"Jim Morrison \& the Lamb" by David E. LeVine (1969)

\section{Introduction}

In a period characterized by continual war, nuclear proliferation, ecological devastation and neo-liberal capitalism, the phenomenon of electric rock music emerges as a complex of contradictory forces, both resisting and unwittingly participating in our chaotic drive for planetary extinction. From the perspective of the Anthropocene, the geological period starting with the Industrial Revolution in which human activities have substantively changed the natural environment (Crutzen 2002), popular music narratives dramatize not only our advanced relationship to fossil fuel technology but also the imaginative and poetic reaching for a reality beyond the grasp of the machine. While peace, civil rights and ecology were central concerns of the 1960s counterculture, rock music's relationship to the environment is complex and conflicted. The genre of the popular music biopic is itself metathematic to issues of the Anthropocene, focused as it is on human exceptionalism and the anthropocentric idolization of the species. However, the genre is also characterized by an often complex and critical treatment of the culture, of technology and narratives of stardom.

Reflecting on the films Elvis from 1979 by John Carpenter and The Doors, from 1991, by Oliver Stone, this essay examines the music and representation of the 
rock star in the biopic genre from an eco-critical point of view. Offering an "environmental perspective on culture" (Willoquet-Maricondi 2010: 2), ecocriticism acknowledges the planet as a living biological and geological system. In its literary form, eco-criticism is "the study of the relationship between literature and the physical environment" (Glotfelty 1996: xviii), exploring the representation of elements such as place, weather, nature and animals. Foremost is the recognition that theory is not distinct from practice, marking a paradigm shift "from an unquestioned anthropocentric perspective to an eco-centric one" (Willoquet-Maricondi 2010: 5). According to popular music scholar David Ingram, "underpinning the new eco-aesthetics is the concept of the 'ecological self', a self that acknowledges its relation to the physical environment in contrast to the possessive individualism typical of Western culture" (Ingram 2010: 14-15). Eco-cinema theorist Anat Pick also informs this debate, discussing how filmic representations of the body can be read in terms of vulnerability and the "creaturely poetic", contesting conventional distinctions between human and other animals (Pick, 2011: 5). The term "rock' $n$ 'roll animal" takes on a special relevance to both Elvis Presley, one of the first white musicians to explore animal magnetism in popular music, and Jim Morrison, who took creaturely identification to new heights with his incarnation as Lizard King.

Both Presley and Morrison, as "stars" (Dyer 1998), represent differing ideologies at work in postwar USA: Presley the forces unleashed by the Great Acceleration (Steffen, Crutzen and McNeill 2007) in industrial-consumer culture since WW2; Morrison the ensuing upsurge of late 1960s ecological and antiwar consciousness. These cultural shifts are also reflected in the changing modes of the biopic itself, moving from a focus on "idols of production" (politicians, scientists, inventors) to "idols of consumption" (entertainers) after 1945 (Bingham 2010: 52). The musical and filmic elements of Elvis and The Doors reflect these cultural shifts and we consider ways in which the films manifest or repress this underlying ecological material. Both E/vis and The Doors can claim a certain preeminence. Marshall and Kongsgaard describe The Doors as "the first bona-fide rock biopic" (2012: 347), while Elvis debuts the narrative structure used in biopics like Walk the Line (2005): starting on the cusp of a historic performance, telling the hero's story in flashback, and ending with the promised performance. We will discuss motifs and images of place common to both biopics, including the desert, the car and open highway alongside mythologies associated with the rock musician's journey from stardom to oblivion and burnout. Thus both films share a downward narrative trajectory analogous to that identified by eco-criticism in modernity. They also display themes or motifs common to the horror genre, for 
example, the return of the repressed (nature) in the guise of shadows, spirits and dark possessive forces.

\section{Dawn's Highway ${ }^{1}$}

An early sequence in The Doors moves from aerial shots of the American desert to close-ups of a 1950s car moving across the vast terrain. The Doors' song "Riders on the Storm" (The Doors 1971) plays non-diegetically, reinforcing notions of movement and upheaval. As with Shakespeare's The Tempest, the lyrics draw attention to the physicality and dangers of not just the climate but the natural universe into which humankind is "thrown". The storm is suggestive of disequilibrium and rupture in both human and non-human worlds and, as a metaphor, references trauma: the aftermath of a horrific auto accident witnessed by the child Morrison in the back of the car. That the accident involves the death and injury of Native Americans is seminal, given the fraught relation of indigenous peoples to Western modernity. The scene closes with sounds of Native American rituals, and a shot of the haunted child. Both elements, the child Jim and Native Americans, return to haunt the protagonist. The car, in this reading, signifies modernity, technology, industrialization and the ensuing environmental crisis of the Anthropocene. As such, the "riders on the storm" represent not only existential angst but also, as Morrison saw with great prescience, a culture en route to devastation. Morrison sings "Roadhouse Blues": "Keep your eyes on the road / your hands upon the wheel", both in the film and over the credits, suggesting the deep disconnection between Western teleological progress and the environment through which the road cuts (dir. Stone, 1991; 2009: 1.17.06; 2.15.16).

However, Stone's representation of Morrison, played by Val Kilmer, privileges the white man as a channel for spiritual forces and thus marginalises the ecological relevance of the car accident and the decimation of indigenous peoples by technological colonisation. In contrast, Morrison's music and poetry contextualise this incident in relation to a critique of American capitalism and its war on indigenous ways of life. In "Peace Frog" he laments, "There's blood in the streets, it's up to my ankles [...] Blood on the rise, it's following me" (The Doors, 1970). In this song, the blood of Native Americans at the accident site ("Indians scattered on dawn's highway bleeding") becomes one with the rising blood of materialism, violence and war invading Los Angeles, Chicago and New Haven. Morrison's experimental film made in 1969, HWY: An American Pastoral, its title acknowledging the pastoral poetic tradition, also foregrounds the car and the highway as symbolic of US culture. In this film Morrison walks across the road to cover a coyote hit by a car. He stands ceremoniously over the stricken coyote as if lost in a moment of grief and creaturely connection. The accident is theorized by Paul Virilio and Sylvere Lotringer (1983) as one of the determining factors of 
the industrial age. Isolating each technological invention in terms of its accident, they present the concept that a machine can never be anything more than its ensuing mechanical malfunction and destruction. From this perspective, and no doubt from Morrison's, Western culture is the accident, a colossal (heat) machine reeling out of control.

Carpenter's film Elvis, starring Kurt Russell, opens similarly to The Doors sequence described above, with two Cadillacs making their way through the Western desert. In this instance the non-diegetic music, "Mystery Train" (McDowell 1979), foretells the arrival of Presley in Las Vegas in 1969. The song's "long black train" of desire, loss and death evokes the uncanny and engages the narrative on multiple levels. Both celebratory and disquieting, Carpenter's repeated use of the song, always in the context of travel, suggests that Presley's journey is fraught with peril. Imagery of trains, cars and highways in American blues and folk music connotes freedom, wilderness (and its control), sexuality, self-determination and modernity and thus transitions effortlessly into the staple mythologies of rock music. While signifying wealth and stardom, this car also symbolizes Presley's imprisonment. His arrival in Las Vegas, amongst the flashing billboards and empty signage, is less than majestic. In a desert city fueled by stolen water, consumerism and oil, Presley steps out of his Cadillac to be immediately surrounded by bodyguards, exiting one prison to find himself in another, the gaudy red rooms of a casino hotel. Greil Marcus notes that in Presley's life, the Cadillac signifies a Faustian pact: "a perfect symbol of the glamour of his ambition and the resentments that drove it on" (Marcus 1982: 184187) and, in a song like "Long Black Limousine"(RCA 1968), a symbol of death. The opening sequence in Elvis could be a funeral procession.

\section{Desert Solitaire}

The US desert locale common to both opening scenes incarnates the mythology of West Coast 1960s rock music. From the perspective of the Anthropocene, rock music's synergy with the desert is both ambiguous and prescient. In the context of global warming, the desert signifies the changing of human habitats, from fruit bowl to dust bowl. That Presley should find himself in the Nevada desert, nervously contemplating his return to the stage in July 1969, certainly suggests the star's inner emptiness and alienation. Again, the soundtrack heightens Presley's anomie - combining hotel lobby music with the Western blaring from Presley's TV. Cut off from the wide-open plains that the programme depicts, Presley sits anxiously on his chair, watching cowboys and Indians race across the screen, their screeching and whooping reflecting his stage fright. 
While the desert locale in Carpenter's film may signify Presley's disillusionment, in The Doors it is the bedrock of Morrison's inspiration ("Earth, snakes and fire" as guitarist Robbie Krieger sums up his singer's themes [dir. Stone 2009: 20.05-20.08]) and his link to First Nation peoples. Our first sight of the adult Morrison is in the desert, as if a desert creature, hitching a ride to LA. Native American culture and notions of shamanism appear in his student films, attracting the derision of fellow students, symbolizing his move away from anthropocentric middle class American values. In his song "When the Music's Over" Morrison laments, "What have they done to the earth? What have they done to our fair sister? Ravaged and plundered and ripped her... tied her with fences and dragged her down" (The Doors 1967). Laurence Coupe, in his survey of the influence of Beat poetry on the 1960s rock scene, contends that it was the eco-perspective of the Beats that helped shape the ensuing environmentalism of 1960s rock. Discussing The Doors, he declares them to be "the first rock group to express consistent concern over environmental destruction" and that Morrison's work relates specifically to the Beat poetry of Gary Snyder in his foregrounding of indigenous cosmologies (Coupe 2011: 174). Morrison reinvented himself, in a Romantic sense, as an animal god -- "I am the Lizard King!" (dir. Stone, 2009: 26.38) -- and as a shaman in touch with "the [great] serpent" symbolising life (dir. Stone: 28.00-28.20), which signals a concern with animal sentience and creaturely consciousness (Pick 2011) while also playing into rock mythologies of masculine power. Morrison as Lizard King is inciting humanity to move out of its "torpor" and back into "the moment of origin...so they may be cured of the disease of linear history" (Coupe 2011: 173). Morrison seems to be reaching for interspecies communication through rituals enacting snake or lizard consciousness, thrashing and writhing in stage performances throughout the film in a shamanistic trance. As he explains to girlfriend Pamela Courson (Meg Ryan), the shaman is "the one who makes you crazy", who "gets into a peyote trance... has a vision and the whole tribe is healed" (dir. Stone, 2009: 11.52-12.00).

\section{With Lions in the Night $^{2}$}

The Doors also refers to early animal rights activism. Its recreation of the infamous 1969 Miami concert includes an audience member giving Morrison a lamb, calling out to the crowd, "Hey, look at this beautiful living thing, you wouldn't eat my little friend would you? Come on man. Love animals, don't eat them" (dir. Stone, 2009: 1.48.02-1.48.12). The incident is based on the real life action of an animal activist, Lewis Marvin, the leader of a commune called Moonfire (Forwood 2013: web source). Marvin knew Morrison. He was an early supporter of The Doors and apparently the band played one of their first concerts at his house in 1966 (Davis 2004). The film represents Morrison in the Miami concert as manic and out-of-control, culminating in his arrest for indecent exposure. Yet 
photographs taken at the real concert showing Morrison holding the lamb suggest other readings -- the look on Morrison's face is of wonder and knowing. For an eco-critical reading of the film, this scene is pivotal. The global "animal industrial complex", as defined by John Sorenson, is not only environmentally unsustainable but one of the main drivers of species extinction and climate change (2014: xii). In a sequence representing the band's 1968 San Francisco concert, images of a Native American ghost dance are superimposed with Morrison as he performs "Not to Touch the Earth". Morrison is shown partaking in the tribal dance; "Not to touch the earth / Not to see the sun / Nothing left to do, but / Run, run, run / Let's run" (Elektra 1968). He metaphorically conjures the spirits and animal guides that he refers to in lyrics such as "Celebration of the Lizard" (Elektra 1970) - the snake, the lizard and the lion- read by Courson at the fated dinner party where, ironically, the subtext of carnism surfaces as Morrison stomps on the Thanksgiving duck.

The sequence in which Morrison and the band take a psychedelic trip in the desert evokes aspects of a primal consciousness. It is introduced with the opening chords to "The End" (Elektra 1967), a song alluding to ritual journeys to otherworldly, taboo destinations. Images of Morrison superimposed over spiralling stars dissolve into an aerial view of the desert while an eagle glides through the darkening sky, symbolizing movement into uncertain, brooding nature. Suddenly, a car races madly through the dunes, throwing up clouds of dust. The members of The Doors and their girlfriends are shown clambering up sand dunes and dancing wildly across the terrain until, gathered into a circle, Morrison tells everyone to close their eyes and "kiss the snake" (dir. Stone, 2009: 28.50). Shadows, silhouettes and subjective camera effects connote a transformed reality, a sense that "the universe is one and everything is beautiful" as Courson says to Morrison (dir. Stone, 2009: 12.46-12.53). As the trip intensifies, Morrison sees a Native American on a white horse and follows him to a cave where he encounters a mountain lion and a lizard, symbols for his entry into a world of spirits and animal guides sacred to the indigenous peoples of America (O'Brien 2016). Inside, he faces yet again the Native American ghost. A montage of cave drawings, lights and shadows flicker over faces and eyes. Suddenly, the narrative flashes back to the car accident in his childhood and the image of the dead Native American on the roadside. Back in the cave, the camera focuses tightly on the reflection in the Native American's eyes, pulling out to reveal Morrison performing at the Whiskey A Go-Go in 1966, implying a mystical union of souls.

This extended experimental sequence is the closest The Doors gets to placing Morrison in nature and thereby exploring his ideas about the biological world, although ironically the group's arrival in a car desecrates an ecologically pristine 
area of desert. The sequence suppresses consideration of the desert environment and the creatures it harbors to the developing narrative of Morrison's individual character. Morrison's real life identification with the desert and, specifically, with desert animals is reminiscent of the work of Edward Abbey, in particular his 1968 book Desert Solitaire, albeit predating it by two years. Stone's failure to dramatize such meaningful aspects of Morrison's musical and conceptual perspective lends weight to criticisms that his film is a personalized fantasy of the era. Members of The Doors consider that Stone represented Morrison as an "out of control sociopath" (TIME 2016: web source) while Ray Manzarek stated, "The Doors movie is a pack of lies" (Classic Bands 1991: web source).

\section{"I'm going back to see my mother" ${ }^{\prime 3}$ Elvis and nature}

Ingram writes: "Advocates of folk music claim that authenticity in music derives from the performer or style of music being close to nature" (2010: 44). The star's relationship to nature is a recurrent theme in Elvis. As a boy, Presley is associated with natural Southern US settings, on riverbanks and in small family gatherings. An extended flashback transports the viewer from Las Vegas in 1969 to a Southern wood, a scene introduced with acoustic guitar fading into diegetic nature sounds. The boy Elvis is laying flowers at the grave of Jesse Garon, his twin who died at birth. He addresses Jesse as if he is still alive - this supernatural motif develops the idea of Presley's second, possibly ecological self. A storm is brewing and his mother Gladys (Shelley Winters) is frantically calling for him. The storm stands for the psychological trauma just experienced by the young Elvis in speaking with his dead twin, but the forces of nature are also presented as physical entities in themselves, phenomenon that assail the hardworking country community as they go about their daily lives. Ingram contends that this notion of nature as a force, threatening and hostile, relates to a more complex notion of the pastoral genre, a kind of "anti-pastoral" (2010: 57) which Carpenter explores in the film's narrative.

Presley is also associated with animals in these early scenes [dir. Carpenter, 2010: 15.38-15.40]: by being called a "squirrel" by schoolmates mocking the length of his hair, another symbol of natural growth; by his performance of "Old Shep", a classic country song about a sheepdog, at a high school talent contest; and later in his self-reference as "clumsier than a mule in Sunday school" when he has problems acting in his films (dir. Carpenter, 2010: 1.08.20-1.08.22). This reference is part of a pattern of allusions to Presley's bodily movements, which were key to his impact on stage and on screen. Actor Kurt Russell throws himself unreservedly into imitating the manic energy of Presley's stage performances, but these same performances make him subject to censure - he becomes a watched body. Here the film makes a summary exploration of the conservative reaction to his dangerous sexuality. The director of The Ed Sullivan Show insists that Presley be filmed only above the waist and reviewers refer to him as "Elvis the pelvis" 
(dir. Carpenter, 2010: 1.12.01-03). He asks Gladys: "Am I vulgar?" and she responds, "You got the energy of two", another reference to his dead twin, as if he is channelling that energy (dir. Carpenter, 2010: 1.12.42-55).

Presley also channels the "natural" energy of African-American music, which we see and hear in the early part of the film. During a car sequence we hear on the soundtrack (or car radio) Rufus Thomas Jr.'s "Tiger Man (King of the Jungle)" (Sun Records 1953), extending the pattern of Elvis animal references along with "Hound Dog" and "Teddy Bear". On two occasions we see Elvis jamming with or listening to black musicians playing acoustic instruments (with connotations to being "natural"); likewise Elvis is only ever seen playing acoustic instruments. Sam Phillips and Marion Keisker (of Sun Records) refer to Presley's "Negro sound" (dir. Carpenter, 2010: 37.16-37.23). In contrast, country music, a competing but white source of naturalness, has negative connotations, being associated with Presley's failed audition for the Grand Ole Opry, and through the use of bluegrass music to introduce the Arkansas trailer where his mother suffers a fatal heart attack. American country music, steeped in the traditions of the pastoral, is exploited by Carpenter for its thematizations of tragedy and loss. The final aspect of Presley's naturalness is his close relationship with his parents, especially his mother (he's referred to as a "mama's boy" [dir. Carpenter, 2010: 11.07). His association with Sun Records is represented as a surrogate family with Phillips and Keisker as his parents, and the implication that once Elvis leaves (to go to RCA), he is alone.

Childhood scenes (often flashbacks) set in nature are often used in music biopics, for example Ray(2005), Walk the Line(2005) and Get On Up (2014), to suggest an authenticity or creativity lost by the adult star. But these can also suggest environmental themes, linking back to Romanticism and the American Transcendental philosophers such as Emerson and Thoreau. An analysis of the pastoral mode in music uncovers a tradition of ecological thought that spans across a wide range of musical genres. Following the literary eco-critic Laurence Buell, Ingram describes this mode in relation to the elegy, which he defines as "a lyrical meditation" on the loss of nature, and satire, "a denunciation of those deemed responsible for that loss" (2010: 52). Presley performs a number of pastorals in the film: for example "Wayfaring Stranger", as a boy on the porch of his family's shack, the lyrics lamenting a life spent away from the "beautiful fields" (trad). Morrison's songs and poetry also work in the pastoral mode. A sequence near the beginning of The Doors has Morrison's poetry from An American Prayer (Elektra 1978) read over scenes of LA at night, becoming a powerful elegy lamenting and reflecting on a disappearing nature. Yet Stone fails to employ effectively the cutting pastoral satires produced by The Doors, songs that 
denounce the generals, politicians and priests who are actively destroying the environment as in "The Soft Parade" (Elektra 1969), though a disturbing TV montage of Vietnam War footage is played to "When the Music's Over" (Elektra 1967).

As Presley's career takes off he moves away from nature and loses his composure. His naturalness comes under attack from the establishment, he is drafted into the army and his mother becomes increasingly unwell. Presley's relationship to her is metaphorical for his narrative journey. Her disquiet markedly increases as the family migrates to the Graceland mansion, a symbol of wealth and isolation (its theme in the film is "Heartbreak Hotel"). We see her feeding chickens in front of its imposing neo-classical facade, connoting her alienation. Its highly stylised interiors and chocolate-box colour palette emphasise artifice, as does the artificial Christmas tree of which Gladys remarks, "I never knew they made any Christmas trees like that". Turning to Elvis, she notes "Your hair's black" (Presley has recently had it dyed) and that she is "feeling poorly". Elvis offers her a mink coat (replacing animals with animal products) but she objects that "it's too hot" for her to wear such an item. He also gives her a pink Cadillac, which she can't drive (dir. Carpenter 1979, 2010: 1.21.131.22.28).

Presley's drafting into the US army precipitates a crisis. While Carpenter plays down the implications of Elvis's induction into the military/industrial complex (Elvis gets a haircut), he does set a key scene in a trailer amid the oil derricks of Arkansas (Presley trained at Fort Chaffee). This is the second time in the film that Carpenter visualizes the geological reality of fossil-fuel extraction, and the oil-rigs work unconsciously to situate Presley's story with the Cold War and the militarization of the planet. Bluegrass music introduces the scene as Gladys, initially happy to be out of Graceland and in a more intimate, familial setting, rambles, addresses Elvis as "Jesse", collapses in front of a refrigerator (shortly after a discussion about her animal-fat-heavy cooking) and dies later in hospital. The implication is that Elvis's success, and his pact with industrial modernity, has killed her. It is a theme that persists in the film as pertaining to the value of success. In the trailer at night, a close-up frames grieving Elvis sitting where his mother sat, with his shadow stark against the white fridge. A figure approaches out of the darkness and Elvis, delusional, addresses him as "Jesse" (dir. Carpenter, 2010: 1.33.20).

\section{Ghosts and eco selves}

The recurring use of shadows in Elvis can be read as a form of haunting. The concept that Presley is divided is initially represented in the childhood rural scenes where he addresses his own reflection in a pool of water (talking to Jesse). In later scenes this hidden or other self is presented using silhouette and shadow, 
a motif that suggests Presley's alienation and premonition of death. The idea of the haunted rock star is a characteristic of both films. Carpenter directed Elvis just after his success with Halloween (1978) and recycles some horror motifs here. ${ }^{4}$ Carpenter's concern with ghosts and doubles can also be read as an exploration of co-subjectivity and, by association, the notion of a more authentic eco-self in conflict with a tormented and lost "ego-self" (Naess 2008). This idea was developed by Arne Naess in his concept of deep ecology, a philosophy that places equal value on all living and non-living elements of the universe. Naess contends that the concept of the ecological self transcends the anthropocentric ego and realizes itself in relation to the planet and other living beings. Morrison grasps for a more meaningful sense of self in his recurrent encounters with Native American spirits and with Patricia Kennealy, a journalist and self-professed witch. Kennealy promises to help Morrison get in touch with a primal energy source through her knowledge of ancient European ritual and witchcraft. In the film, this is depicted as part of Morrison's general slide into debauchery, drinking and demonism. The drive to nature and, as Kennealy states, the maternal "goddesses of the grain" is also the drive toward damnation (dir. Stone, 2009: 1.00.58). In this context, the recurrent appearance of Native American spirits and, close to the end of the film, Morrison's child self, register as premonitions of death rather than hinting at the possibility of regeneration. Similarly, Elvis is haunted by his dead twin and mother, and this becomes a metaphor for his alienation by fame, technology and modernity.

The idea that nature rejected becomes more dangerous and returns in a repressed form is present in both films. A night-time outdoor concert features a sneering Elvis toying with his fans, in full self-parody mode singing "A Fool Such as I" (McDowell 1979), and clad in his famous gold lamé suit, an obvious symbol of artifice. At one point he kneels and blesses an incoherent female fan, placing a crucifix around her neck. There is a quasi-ritualistic aspect to this portrayal of the worshipped rock idol. Semiotically, this scene again suggests analogies to the horror genre. A sudden cut away to an extreme wide shot (dir. Carpenter, 2010: 1.52.45) from behind stage left reveals the concert as an oasis of light in a surrounding darkness of trees, sky and parked cars. We see the stage lights and the backdrop: the shot reveals the construction of the spectacle and creates a Brechtian alienation effect, an unspecified, distant view of the human drama unfolding, with connotations of menace or nature fallen. Increasingly, Elvis, separated from the "natural" roots of his creativity and from intimacy with others, surrenders to a death wish reflected in his preoccupation with assassination, his black clothing, and his obsession with his shadow self, Jesse. "Gonna see you and 
mama soon", he says to his shadow in one late scene (dir. Carpenter, 2010: 2.32.42), while his Vegas concert becomes a "do or die" affair.

Presley's journey towards a diabolical nature is repeated by Morrison in his demonic drinking of blood and frenzied dancing with the witch. Both singers move from their creative source - in Morrison's case the Western desert - towards urban modernity and a technological death. For the Doors, this means the East Coast and New York, the height of artifice and decadence, symbolised by their visit to Andy Warhol's Factory (where a screen shows US bombers dropping bombs), and secondly (as in Elvis) by The Ed Sullivan Show's attempt to censor them. The obvious difference is that while Presley's "natural" creativity relates to his family ties and to African-American culture, Morrison's relates to his "freedom", that is, his lack of family background (like the early Bob Dylan, he pretends he has no parents) and his identification with Native Americans. This reflects how the 1960s counterculture more openly rejected tradition and found new sources of authenticity by identifying with other repressed minorities and with nature.

\section{Ghosts of electricity}

The contradictions inherent in rock music's identification with nature are in many ways symbolized by the phenomenon of electricity at rock's core (Ingram 2010: 123). For Eric Mottram, "the electro-visual aspects" of a rock performance - the "wires, microphone and speakers - gear the human body into the energy circuitry as much as an astronaut becomes the cyborg of his capsule" (1988: 183). Both Morrison and Presley were stars empowered by the electronic nature of the stage, lighting and other mass media devices, and this feature is given emphasis in both films. In a scene depicting Morrison's bedroom, the camera pans over his books, including Marshall McLuhan's Understanding Media (1964) with its mantra "the medium is the message". Ingram explains that electricity has often attracted the attention of "mystical thinking" and that it was easy for the 1960s counterculture to embrace electronic rock as a means of accessing cosmic consciousness (2010: 61). Both films, however, also depict a number of scenes where the technological conjoining with the body is shown to be unstable and a catalyst for emotional breakdown. For example, the sense of oneness with the electronic universe is undermined in scenes where both Presley and Morrison, in fits of despair, destroy their television sets. In Elvis, Presley, watching a disparaging news item of his arrival in Las Vegas, simply shoots the television. In The Doors, Morrison throws a TV into a recording studio wall after discovering that "Light My Fire" (Elektra 1967) is now an advertising jingle.

Although the electronic sublime was powering the rock explosion, there was an equal focus on the body, sexuality and the senses, as with the song "Touch Me" (Elektra 1969). The body signified the site of natural energy even though on 
stage it was the place where the new audio technologies enabled by fossil fuels converged. Signifying a break with the past, with the mechanized culture that had culminated in the war in Vietnam, the body in a Foucauldian sense was political. Tellingly, a scene rejected by Stone but included on the 2006 DVD (dir. Stone) of extras shows Morrison performing "Unknown Soldier" at New Haven in 1968. Re-enacting the original footage of Morrison performing this song, Kilmer's mock execution highlights the vulnerability of the body and the anti-war sentiment that underscored much of Morrison's work. As Virilio (1990) reiterates, war is the ultimate attack on the environment and, in relation to Vietnam, a machine that moved mercilessly across the country, intent on defoliating forests and incinerating all biological life. Stone's focus on Morrison's eccentricities would appear to sideline the singer's political relevance. The performances of "Unknown Soldier" were ahead of their time as critical performance art and a radical act of rebellion by Morrison, given his father's personal involvement in the military, revealed by Kennealy in the scene backstage before Morrison is attacked and pepper-sprayed by a policeman. The focus on anarchic bodily and natural energy references Friedrich Nietzsche (1968), who Morrison quotes in his student film: "This world, a monster of energy, without beginning, without end" (dir. Stone, 2009: 0:08:37-41). Stone, who cameos as the film tutor, recreates the UCLA screening of Morrison's film, showing the juxtaposition of images of the shaman with images of German fascism that suggests a bitter critique of modernity and the dark forces unleashed by the Enlightenment. Stone's biopic foregrounds the demonic aspects of this energy to heighten the image of Morrison as 'wild child' of the 1960s counterculture. However, the ecological unconscious of the film returns in a number of ways, especially in the connection of Morrison's Dionysian self to the animal. The symbolism of the body as animal and the musical performance as animalistic connects to Pick's notion of the creaturely poetic discussed earlier, that is, the idea that vulnerability, corporality and beauty exceed the boundaries separating the species (2011).

\section{Conclusion}

"The Movie will begin in five moments / The mindless voice announced / All those unseated will await the next show...Did you have a good world when you died? Enough to base a movie on?" (Morrison 1978). The Doors opens with Morrison in the studio making his solo recordings of poetry that became $A n$ America Prayer (Elektra 1978). It is a narrative device that Stone returns to again in the film, and it has a metacinematic function that parallels Morrison's interest in the cinema. In the context of the Anthropocene, the cinematic references in 
the music and writings of Morrison draw attention to the uncanny presence of this technology, one that is encrypting animals even as they disappear from the planet (Lippit 2008) in an apocalypse scientists describe as the Sixth Great Extinction (Leakey and Lewin 1995). The spectral quality of these disappearing creatures haunts contemporary consciousness and, as Morrison's oeuvre suggests, returns in such a way as to unsettle our anthropocentric ideologies.

Cinematic devices such as the close-up, as discussed by Richard Dyer, are central to Hollywood's development of the movie star phenomenon through this period (1998:16). Revealing of emotion and suggestive of psychological interiority, the close-up provided immediate access to the star and a new kind of media ownership. As the biopics of Presley and Morrison both illustrate, the relationship of the close-up to music is seminal in the genre, suggesting, as in numerous scenes with Presley and Priscilla, communication of unspoken emotional material. The music in this sense is presented as giving access to the characters' innermost feelings. In a culture where the feeling self (the eco-self) is predominately repressed, this foregrounding of affect and emotion plays a strange and uncanny role in the films. Biopics allow for identification not only with the star but also with the music, with the memories and experiences of interiority foremost for the spectator. As a form of psychic haunting, the music plays a role in the films similar to Pick's notion of creaturely poetics, that is, it embodies the very thing that unites humans with other sentient beings.

As cultural texts, both The Doors and Elvis are revealing of the historical conditions of their making. From an eco-critical perspective, the films both repress but cannot control readings of ecological demise that define the Anthropocene. Carpenter, the director of horror, brings to his portrayal of Presley an uncanny, dark and brooding malice relevant to an age of social and ecological decline. Stone's biopic of Morrison, by contrast, while belonging to this director's cycle of films about recent US history including Platoon (1986), Born on the 4th of July (1989) and Nixon (1995), somehow manages to evade the political context. In the context of the Anthropocene, what is perhaps most relevant about Stone's relation to Morrison is the fact he first heard The Doors' music while on active service in Vietnam (Stone cited in O'Hop, 1997: 182).

Watching James Dean on his home cinema, Presley repeats the famous lines from Rebel Without a Cause (dir. Ray, 1955), "Boy, if I had one day when, when I didn't have to be all confused... and if I felt that I belonged someplace" (dir. Carpenter, 2010: 2:11:00). This sense of a vulnerable human subject searching for some kind of truth is common to both biopics and in many ways defines the impulse of much of the era's popular music. Both Presley and Morrison represent in their artistic careers different social responses to this era of American Empire, militarization and atomic proliferation, and the films that tell the stories of these performers cannot help but convey the contradictions of their age. 


\section{Acknowledgement}

Photograph by David E. LeVine, "Jim Morrison and the Lamb" (1969), Dinner Key Auditorium, Miami, Florida, US, is reproduced here with permission from the photographer (www.TreeO.com).

\section{Endnotes}

1 The Doors. 1970. "Peace Frog". Morrison Hotel. Elektra. US.

2 The Doors. 1969. "The Soft Parade". The Soft Parade. Elektra, US.

3 "Wayfaring Stranger". Traditional folk song, performed in Elvis.

4 As Bingham observes, the biopic was experiencing a low ebb through the 1970s and, while consistent with the trend of being made for TV, Elvis is also prescient of the revitalization of the genre through the 1980s and beyond.

\section{References}

\section{Bibliography}

Abbey, E. 1968. Desert Solitaire, A Season in the Wilderness. New York: Ballantine Books.

Bingham, D. 2010. Whose Lives Are They Anyway? The Biopic as Contemporary Film Genre. New Brunswick, New Jersey: Rutgers University Press.

Classic Bands. 1991. "Gary James' Interview with Ray Manzarek of The Doors". Classicbands.com. http://www.classicbands.com/RayManzareklnterview.html Accessed: 31 January 2017.

Coupe, L. 2011. Beat Sound, Beat Vision: The Beat spirit and popular song. Manchester: Manchester University Press.

Crutzen, J. P. 2002. Geology of Mankind. Nature 415: 23 http://dx.doi.org/10.1038/415023a Accessed: 31 January 2017.

Davis, S. 2004. Jim Morrison: Life, Death, Legend. UK: Penguin.

Dyer, R. 1998. Stars. London: British Film Institute.

Forwood, A. 2013. When The Music's Over: The Rise and Fall of the Hippie Generation - Part 2, Nov 13, 2013. Exposing the Truth: http://exposinginfragard.blogspot.co.nz/2013_11_01_archive.html Accessed: 31 January 2017. 
Glotfelty C. 1996. Introduction: Literary Studies in an Age of Environmental Crisis in Cheryll Glotfelty and Harold Fromm (Eds.) The Ecocriticism Reader, Landmarks in Literary Ecology, Athens, Georgia: University of Georgia Press, $\mathrm{xV}-\mathrm{xxxvii}$.

Ingram, D. 2010. The Jukebox in the Garden: Ecocriticism and American Popular Music Since 1960. Leiden: Brill.

Leakey, R. and R. Lewin. 1995. The Sixth Extinction, Biodiversity and its Survival. London: Weidenfeld and Nicolson.

Lippit, A. 2008. Electric Animal: Toward a Rhetoric of Wildlife. Minnesota: Minnesota Press.

Marcus, G. 1982. Mystery Train: Images of America in Rock ' $n$ ' Roll Music. New York: Plume.

1991. Dead Elvis: A Chronicle of a Cultural Obsession. Cambridge, MA: Harvard University Press.

Marshall, L. and I. Kongsgaard. 2012. Representing Popular Music Stardom on Screen: The Popular Music Biopic. Celebrity Studies, 3:3: 346-361.

McLuhan, M. 1964. Understanding Media: The Extensions of Man. London, NewYork: MIT Press.

Mottram, E. 1988. Blood on the Nash Ambassador: Investigation in American Culture. London: Hutchinson Radius.

Naess, A. 2008. The Ecology of Wisdom: Writings by Arne Naess. Ed. Alan Drengson and Bill Devall. Berkeley: Counterpoint.

Nietzsche, F. 1968. The Will to Power. (Ed. W. Kaufmann). New York: Vintage. O'Brien, S. 2016. Native American Religious Traditions. New York; Oxford: Routledge.

O'Hop, S. E. 1997. Enough to Base a Movie On? In D. Kunz, Ed. The Films of Oliver Stone (The Scarecrow Filmmakers Series). Lanham: Scarecrow Press. Rowman and Littlefield.

Pick, A. 2011. Creaturely Poetics: Animality and Vulnerability in Literature and Film. New York: Columbia University Press.

Sorenson, John. 2014. 'Introduction: Thinking the Unthinkable'. In John Sorenson (Ed.) Critical Animal Studies, Thinking the Unthinkable. Toronto: Canadian Scholars' Press Inc, xi - xxxiv.

Steffen, W., P. Crutzen, and J. McNeill. 2007. The Anthropocene: Are Humans Now Overwhelming the Great Forces of Nature? Ambio 36/8 (December): 614-21.

TIME. 2016. Real Life Rock Bands on Screen.

http://content.time.com/time/photogallery/0,29307,1973216_2089286,00.ht ml. Accessed: 5 May 2017.

Virilio, P., Lotringer, S. 1983. Pure War. New York: Semiotext(e) . 
Virilio, P. 1990. Popular Defense and Ecological Struggles. New York: Semiotext(e).

Willoquet-Maricondi, P. 2010. Framing the World: Explorations in Ecocriticism and Film. Virginia: University of Virginia Press.

\section{Videography}

Born on the 4th of July. 1989. Dir. Oliver Stone. Ixtlan.

Elvis. 1979, 2010. Dir. John Carpenter. Dick Clark Productions.

Get On Up. 2014. Dir. Tate Taylor. Imagine Entertainments/Jagged Films/Wyolah Films.

HWY: An American Pastoral. 1969. Dir. J. Morrison, Lisciendro, Ferrara, Hill. Nixon. 1995. Dir. Oliver Stone. Cinergi Pictures Entertainment, Hollywood Pictures, Illusion Entertainment.

Platoon. 1986. Dir. Oliver Stone. Hemdale, Cinema 86.

Ray. 2005. Dir. Taylor Hackford. Universal Pictures.

Rebel Without A Cause. 1955. Dir. Nicholas Ray, Warner Bros.

The Doors. 2009. Dir. Oliver Stone. Carolco Pictures Inc, Tristar Pictures, Imagine Entertainment.

The Doors. 15 Year Anniversary Edition. 2006. Dir. Oliver Stone. Lions Gate Entertainment.

Walk The Line. 2005. Dir. James Mangold, Fox 2000 Pictures

\section{Discography}

Doors, The. 1967. The Doors. Elektra, US.

Doors, The. 1967. Strange Days. Elektra, US.

Doors, The. 1968. Waiting for the Sun. Elektra, US.

Doors, The. 1969. The Soft Parade. Elektra, US.

Doors, The. 1970. Morrison Hotel. Elektra, US.

Doors, The. 1970/1996. Absolutely Live. Elektra, US

Doors, The. 1971. LA Woman. Elektra, US.

McDowell, Ronnie. 1979. "Elvis": The Soundtrack of the Movie. Arcade. US.

Morrison, Jim (and The Doors). 1978. "The Movie." An American Prayer.

Elektra, US.

Presley, Elvis. 1969 "Long Black Limousine". From Elvis in Memphis. RCA Victor, US.

Thomas, Rufus. 1953. "Tiger Man (King of the Jungle)". Single. Sun Records, US. 